УДК 376.1

\author{
Педагогическая помощь ребёнку раннего \\ возраста с нейротравмой: серия игр, \\ направленных на восстановление \\ продуктивного взаимодействия со взрослым
}

\author{
А. И. Камелькова, П. П. Колдышева, \\ Д. М. Мартышевская, П. А. Тарновская \\ Московский педагогический государственный университет, \\ 2. Москва
}

Аннотация.

Введение. Статья посвящена актуальным вопросам реабилитаиии детей с нейротравмой (в условиях стачионара) педагогическими средствами. Целью исследования стала разработка серии педагогических занятий, направленных на восстановление у ребёнка после нейротравмы способов взаимодействия со взросльим. Представлена динамика восстановления сочиальных умений у ребёнка с тяжёлой черепно-мозговой травмой, раскрыто содержание коррекционной работы, включающей в себя серию игр на взаимодействие.

Материалы и методы. Описан клинический случай: ребёнок, мальчик Д., 2,7 г., поступивший на лечение в стационар с закрытой черепно-мозговой травмой, тяжёльмм ушибом головного мозга. Использованы следующие методы: педагогическое обследование, диагностическое обучение, наблюдение.

Результаты исследования. Разработана серия педагогических занятий для восстановления у ребёнка с тяжёлой черепно-мозговой травмой умений взаимодействовать со взрослым. По результатам педагогического обследования у ребёнка Д. отмечалась положительная динамика восстановления.

Заключение. Данная проблематика может получить развитие через разработку новых методов коррекиионно-педагогической помощчи детям с нейротравмой на раннем этапе. Результаты экспериментальной работы могут быть использованы в практической деятельности педагогов-дефектологов, работающих с детьми, перенёсшими тяжёлую черепно-мозговую травму. 


\section{Ключевые}

слова:

ранний возраст, нейротравма, сочиальный контакт, взаимодействие, черепно-мозговая травма, реабилитация, коррекционная помощь, ребёнок с нейротравмой, ребёнок с черепно-мозговой травмой.

\section{Для цитирования:}

Камелькова А. И., Колдышева П. П., Мартышевская Д. М., Тарновская П. А. Педагогическая помощь ребёнку раннего возраста с нейротравмой: серия игр, направленных на восстановление продуктивного взаимодействия со взрослым // Педагогический ИМИДЖ. 2019. № 4 (45). С. 598-614.

DOI: 10.32343/2409-5052-2019-13-4-598-614

Дата поступления статьи в редакцию: 27 марта 2019 г.

\section{Введение}

Нейротравма - проблема, требующая особого внимания со стороны здравоохранения, так как, по данным Всемирной организации здравоохранения, травмы центральной нервной системы сопряжены с особо высокими рисками смерти и инвалидизации по сравнению с другими видами травматических повреждений. В современном мире последствиями нейротравм становятся огромные потери как для отдельных людей и семей, так и для общества в целом $[14 ; 24]$.

Нейротравма, полученная в раннем детстве, оказывает негативное влияние на проявление у ребёнка ведущих мотивов общения, в котором взрослый становится партнёром, образцом для подражания, экспертом оценки знаний и умений ребёнка. Общение со взрослым утрачивает свой культурный смысл, и только редкая эмоциональная реакция в сочетании с непроизвольными движениями может указывать на специфичность психической активности в ходе течения травматической болезни [20 и др.].

Нейротравмы у детей распространены широко и нередко ведут к возникновению задержек психического развития, интеллектуальным нарушениям, отклонениям в сенсорной, эмоциональной и двигательной сферах и др. Опыт педагогической работы в практике коррекционной работы с детьми, имеющими выраженные нарушения развития, позволяет обращаться к дефектологическим «находкам» и использовать самые эффективные разработки с детьми, перенёсшими нейротравму [4; 10 и др.].

Цель исследования: разработка серии педагогических занятий, содержание которых направлено на восстановление у ребёнка после нейротравмы социальных умений в коммуникации и взаимодействии с близкими и новыми взрослыми. 


\section{Педагогический ИМИДЖ}

ГАУ ДПО ИІР0

Методологией исследования послужили положения культурно-исторической концепции развития личности: о ведущей роли взрослого в социальном развитии ребёнка, о процессах интериоризации и экстериоризации (Л. С. Выготского), о ведущей роли чувственного познания в психическом развитии ребёнка (А. В. Запорожец).

Согласно данным Всемирной организации здравоохранения (ВО3) нейротравма определяется как травматическое повреждение центральной нервной системы, и, соответственно, это понятие включает в себя черепно-мозговую (ЧМТ) и позвоночно-спинальную травму (ПСТ) $[13 ; 22 ; 19 ; 24]$. Тем не менее в русскоязычных публикациях понятие термина «нейротравма» не полностью сформировалось.

Некоторые авторы включают в это понятие травмы не только центральной, но и периферической нервной системы. Другие употребляют термин «нейротравма» как примерный синоним черепно-мозговой травмы [17]. Ряд русскоязычных авторов тем не менее использует термин в соответствии с определением ВОЗ, то есть для обозначения травм ЦНС $[13 ; 18]$.

Среди детей нейротравмы распространены достаточно широко: в период 2003-2012 гг. в России только ЧМТ получили более двух миллионов детей, из них более 16 тысяч погибло, а более 43 тысяч детей получили инвалидность [4]. ПСТ же составляют не менее 1,5 \% от числа всех травм [19].

Согласно современным представлениям на последствия нейротравмы у детей влияют как характер повреждения и возраст ребёнка, так и объём (помощь должна быть комплексной), своевременность профессиональной помощи, которую получил ребёнок $[5 ; 21]$. Одним из видов помощи, который необходим ребёнку после нейротравмы, является коррекционно-педагогическая помощь $[10 ; 11 ; 14 ; 5]$.

В раннем возрасте коррекционно-педагогическая помощь детям после нейротравмы особенно значима, поскольку травматическое поражение незрелого головного мозга приводит к тяжёлым психофизическим нарушениям, обусловливающим искажение, а в ряде случаев и значительные изменения в динамике психического развития [25].

Родители детей раннего возраста с нейротравмой длительное время не могут смириться с ситуацией ограничений в развитии своего ребёнка по причине травматизации. Ведь период раннего детства - это развитие и закладка ведущих психических новообразований, которые обеспечивают самостоятельность и взросление детского организма.

Известно, что масштабность этого процесса представлена исследователями в описании закономерностей и особенностей детского развития. Поскольку раннее детство представляет собой уникальный этап в жизни ребёнка, который характеризуется наиболее быстрыми темпами физического и психического развития и овладения различными умениями и навыками. На данном этапе происходят интенсивный рост организма, развитие физической активности, становление нервно-психических процессов и личностных качеств. Многочисленные исследования в области медицины, психологии и педагогики доказывают, что вопросы развития и воспитания детей раннего возраста были актуальными (Н. М. Щелованов, Н. М. Аксарина, М. Ю. Кистяковская и др.). Над проблемой физического воспитания работали К. Д. Губерт, Л. Г. Голубева, 3. С. Уварова. 
Особенностям речевого развития детей посвящены разработки методических рекомендаций В. А. Петровой, Е. К. Кавериной, Г. Л. Розенгарт-Пупко. Проблема становления предметной и игровой деятельности освещена в работах Р. Я. Лехтман-Абрамович, Е. И. Радиной, С. Л. Новоселовой.

Отечественные исследователи подчёркивают, что социальная ситуация развития ребёнка в раннем возрасте определена повышенным интересом к миру вещей, потребностью в овладении предметами [1; 7; 8 и др.]. Содержанием общения является предмет и действие с ним. Задачей взрослого становится организация предметной деятельности через общение, в процессе которой ребёнок осваивает социально приемлемые способы взаимодействия с предметом $[15 ; 16]$.

В период раннего детства протекает наиболее интенсивное усвоение способов действий с предметами. Благодаря этому к концу периода ребёнок способен пользоваться бытовыми предметами и играть с игрушками. Становление предметных действий проходит по двум направлениям. Первое - переход от совместного действия со взрослым к самостоятельному, при этом взрослый выступает образцом действия, что позволяет ребёнку сравнивать себя с ним. Второе - развитие средств и способов ориентации ребёнка в условиях осуществляемого действия, что ведёт к овладению специфическими способами действия с предметом, а затем к переносу действия с одного предмета на другой. Итогом появления данного переноса является возникновение игрового действия [23]. К концу раннего детства ребёнок не только осваивает назначение предметов, но и знает их функцию. Происходит возникновение личного действия, осознание себя как личности («Я сам») [20].

В предметном сотрудничестве со взрослым происходит становление речи, что является одним из важнейших новообразований раннего возраста. Речевая активность становится возможной при наличии поставленной взрослым задачи: чтобы быть понятым, ребёнок должен произнести определённое слово. Во время раннего детства происходит развитие понимания речи взрослого и развитие собственной активной речи. В возрасте около одного года у ребёнка появляются первые активные слова, и на протяжении раннего возраста происходит постепенное накопление активного и пассивного словарного запаса. В середине второго года происходит «речевой взрыв», во время которого ребёнок проявляет повышенный интерес к речи, а словарный запас ребёнка нарастает очень быстро. Яркая речевая активность ребёнка заметна на третьем году жизни, когда речь начинает отделяться от наглядной ситуации и становится самостоятельным средством общения.

Развитие предметных действий и речи приводит к появлению игровых замещений, при которых новое называние знакомых предметов определяет способ их игрового использования. Уже к трём годам в благоприятных условиях появляется ролевая игра, во время которой ребёнок, играя, берёт на себя действия другого [8].

Общение со сверстниками имеет огромное значение в личностном развитии ребёнка: этот процесс обеспечивает яркие эмоциональные переживания, ребёнок начинает выделять себя среди других, осознаёт свои особенности [7; $20 ; 23]$.

Таким образом, в онтогенезе выделены определённые достижения раннего 
детства: формирование предметной деятельности; развитие общения со взрослыми, становление общения со сверстниками; появление предпосылок возникновения игровой деятельности; формирование личного действия; развитие экспрессивной и импрессивной речи; активное двигательное развитие; оценка собственных достижений, сознание «Я сам».

В результате рассмотрения данных, полученных во время наблюдений за детьми в стационаре в ходе экспериментальной работы (2018-2019), а также при изучении итогов анкетирования семей, воспитывающих детей после тяжёлой нейротравмы, был сделан следующий вывод: детский травматизм может являться одной из серьёзных причин нарушений развития. Дети раннего возраста после перенесённой травмы по состоянию психической активности во многом похожи на детей, рождённых с патологией развития. Описание характерных особенностей развития при травматической болезни во многом схоже с описанием разных нарушений в развитии детей с органическим поражением центральной нервной системы [3; 14].

Так, на первом году жизни у детей с врождёнными нарушениями развития наблюдаются отсутствие комплекса оживления или недоразвитие его отдельных компонентов, недостаток эмоционально-мимических и голосовых реакций. Эти дети могут бояться взрослого, протестовать против попыток установления контакта, что препятствует общению с ребёнком. Мимика таких детей невыразительна, у них отсутствует интерес к игрушкам, нет выраженной реакции на новизну. У многих детей отмечается недостаточность тонких дифференцированных движений пальцев рук, что в дальнейшем может привести к задержке развития предметных действий. Для речевого развития таких детей характерно отсутствие или бедность гуления и лепета. Понимание речи отсутствует или ограничено [15]. Нарушения речи отмечаются у таких детей и в период раннего детства. Дети с нарушениями в развитии практически не владеют речью, что ограничивает коммуникацию. Ребёнок может использовать несколько лепетных слов или звукокомплексы. Чаще всего коммуникативная функция речи не компенсируется невербальными средствами общения, так как мимика развита очень слабо, дети плохо понимают жесты. Ограниченность в общении и сотрудничестве со взрослым, отсутствие интереса к окружающему миру, задержка в овладении первыми предметными действиями ведут к тому, что у детей не формируется предметная деятельность [3].

К трём годам дети с нарушениями в развитии могут производить действия с предметами, но при этом не учитывают свойства и предназначение предмета. Манипуляции с предметами могут сопровождаться неадекватными действиями. Для детей с нарушениями в развитии характерны особенности общей моторики. Так, овладение прямохождением происходит позже, чем у нормально развивающихся сверстников. Мелкая моторика характеризуется неточностью, рассогласованностью, отсутствует указательный жест. Общая моторная неловкость и недостаточность мелкой моторики обусловливает несформированность базовых навыков самообслуживания [2]. К трём годам отмечаются поведенческие особенности в виде негативизма, капризов, агрессии. Данные проявления затрудняют коммуникацию и совместную деятельность [20]. Ребёнка с нарушениями развития от нормально развивающегося сверстника отличают: отсутствие целенаправленных действий, безразличие к результату, неадекват- 
ные действия; нарушения речевого развития; трудности коммуникации; физическое недоразвитие.

Наблюдения в стационаре за детьми, перенёсшими тяжёлую нейротравму, показывают, что их психическое состояние отличает низкая активность [2; 10$]$. Как правило, отсутствует реакция на происходящее вокруг, эмоциональная реакция на взрослого, на его голос. Слабые реакции могут проявляться при болезненном медицинском воздействии, изменении положения тела, прикосновении. Чаще всего такие дети моторно пассивны. Во время уходовых процедур или воздействия на сенсорные системы дети проявляют реакцию в виде непроизвольных движений мышц лица, скачкообразных движений глаз, пожевывающих движений ртом $[10 ; 14 ; 25]$.

Таким образом, является очевидным, что тяжёлая нейротравма является серьёзной причиной тяжёлого состояния ребёнка, оказывает резкое воздействие на изменение его возрастного и социального статуса: прерываются коммуникативные связи с близкими взрослыми, теряется культурный запас достижений и новообразований возраста, появляется полная зависимость от близкого взрослого.

\section{Материалы и методы}

В статье описан мальчик Д., 2,7 г. Из-за наезда мотоцикла он получил закрытую черепно-мозговую травму. В результате тяжёлого ушиба головного мозга особенно пострадали ствол мозга и левое полушарие.

Впервые мы наблюдали Д. менее чем через месяц после того, как он получил травму. Мальчик лежал на больничной кровати, с катетером и капельницей, в синяках. Он не реагировал на обращённую речь, мало двигался. Глаза Д. были приоткрыты, но фиксации взгляда и стойкого прослеживания не наблюдалось. Мальчик выглядел угрюмо, постоянно отворачивал голову в сторону и не издавал ни звука.

В исследовании были использованы методы наблюдения, педагогического обследования.

Наблюдение за ребёнком проводилось в состоянии покоя и в режимные моменты: фиксировались его реакции на манипуляции ухода и медицинских процедур.

Педагогическое обследование проводилось по методике оценки психической активности [11], протокол включал в себя описание состояния ребёнка по трём линиям развития:

Физическое развитие: в положении лежа - зафиксировано отсутствие точных двигательных действий, действия некоординированные - мальчик не тянулся за предметом целенаправленно, не мог совершить точное действие, действия совершались преимущественно левой рукой, правая рука не задействована, не сформирован захват. Наблюдались наличие непроизвольной фиксации объекта взглядом: взор был неустойчивый.

Познавательное развитие - резко затруднено, так как не наблюдалась фиксация предмета взором, в момент обследования мальчик закрывал глаза или отворачивал голову; не реагировал на сенсорные стимулы.

Социальное развитие: ребёнок плачем отзывался на голос матери, на нового взрослого реагировал негативно (махал руками, повышал голос до крика и стона), контакт доступен был преимущественно на невербальном уровне, путём 
касания, удержания за руку. Речевая активность отсутствовала. В самообслуживании ребёнок был зависим от взрослого. В социальном развитии наблюдалось отсутствие интереса к окружающему пространству, к новым взрослым. В целом, ребёнок вёл себя беспокойно, демонстративно отворачивался от нового взрослого, плакал.

По результатам педагогического обследования ребёнок Д. набрал 10 баллов из 36, что свидетельствовало об уровне непроизвольного реагирования и сочетанных движений, указывало на необходимость создания специальной коммуникативной ситуации для адаптации ребёнка к своему состоянию, к новому пространству и его звукам (в палате) с помощью активных социальных воздействий со стороны взрослого в ситуации предметно-игрового взаимодействия.

В ходе экспериментального исследования была поставлена цель: разработать специальную серию игровых заданий для налаживания с ребёнком доступной коммуникации и активизации его потребности к новому взрослому и окружающему пространству.

Полученная информация в ходе наблюдения за ребёнком и проведения первичного педагогического обследования позволила нам разработать 2 серии заданий, чтобы включить их в диагностическое обучение. Прототипом послужили материалы, используемые в широкой практике коррекционной педагогики и абилитации/реабилитации [3; 12; 14].

\section{Результаты исследования}

Коррекционно-развивающие занятия, направленные на установление социальных контактов для детей, перенёсших нейротравму

СЕРИЯ (1) Предметно-игровых заданий, направленных на установление контакта с ребёнком и налаживание эмоционально-положительного взаимодействия

Методический комментарий: основные методы и приёмы, с помощью которых проигрываются задания, - это эмоциональное вовлечение ребёнка в игру, привлечение его внимания к новому взрослому и предметно-игровым действиям; использование мотивирующих развивающих игр, а также создание игровой ситуации в процессе коррекционно-восстановительной работы [9].

Серия заданий предлагается ребёнку поэтапно:

1. активизация эмоциональных средств в ходе налаживания общения со взрослым и привлечение внимания ребёнка к лицу, к голосу и действиям взрослого;

2. восстановление эмоционального контакта со взрослым;

3. активизация и побуждение к поддержанию эмоционального контакта.

На первом этапе важным аспектом восстановительной работы является активизация эмоциональных средств в ходе налаживания общения со взрослым и привлечение внимания ребёнка к лицу, к голосу и действиям взрослого.

Задание 1. «Посмотри на меня»

Цель: учить ребёнка удерживать взгляд на лице взрослого, привлекать его внимание к голосу взрослого, стимулировать активные звуки речи.

Ход задания: взрослый касается рук ребёнка, поглаживает, произносит его 
имя, здоровается за ручку. Затем произносит звукокомплексы и простые слова, побуждает ребёнка к подражанию: «ага», «ау», «ты», «тётя», «мама» (на выдохе рёбенка с паузированием на вдохе). Чем больше ребёнок включается в «разговор», тем тише становится взрослый, чтобы дать ребёнку возможность прислушаться к собственной речи. Данное задание рекомендовано проводить 2-3 раза в день длительностью по 2-5 минут.

Задание 2. «Весело вместе»

Цель: вызывать оживление (смех) ребёнка.

Ход задания: для того, чтобы вызвать бурную реакцию ребёнка, взрослый то наклоняется близко к лицу, то отдаляется от него, ласково произносит имя ребёнка, различные звуки и слоги, тем самым пытаясь побудить ребёнка к ответной реакции.

Задание 3. "Действие с погремушкой»

Цель: вызывать ответную положительную реакцию на действия взрослого.

Ход задания: у взрослого в руках погремушка, он подходит к ребёнку, ласково улыбается и на расстоянии 20 см от лица негромко звенит погремушкой. Спокойным, доброжелательным тоном взрослый привлекает внимание ребёнка к предмету: «Это погремушка! Как звенит! Ай-ай-ай (на распев) как звенит!», подносит его к рукам ребёнка, проводит им по пальчикам, даёт возможность ознакомиться с новой игрушкой. Если ребёнок положительно реагирует, вкладывает её в руку и помогает звенеть ею, при этом приговаривает «Вот какая погремушка! Как здорово ты звенишь! Какой молодец/умница!»

Задание 4. «Забавные животнье»

Цель: установить эмоциональный контакт со взрослым, побуждение к активному звукоподражанию.

Ход задания: взрослый надевает на руку куклу-корову, показывает ребёнку, спокойным голосом произносит: «Это корова. Му-му-му». Затем перемещает руку в сторону - сначала вправо, наблюдая за тем, следит ли ребёнок за игрушкой, снова произносит: «Му-му-му. Это корова», потом перемещает корову влево так же спокойно, модулируя голосом, озвучивая игрушку. Можно коснуться игрушкой руки ребёнка, при этом приговаривая цепочку лепетных слогов «му-му-му», ожидая от ребёнка ответной реакции - повторения лепета за взрослым.

Комментарии: вместо игрушки-коровы может быть использована любая игрушка, озвучиванию которой можно подражать прямыми слогами или одним звуком (курочка - «ко-ко-ко», гусь- «га-га-га», слон/сова - «ууу-ууу»).

Второй этап - это восстановление эмоционального контакта со взрослым и подражательных умений. На данном этапе могут быть использованы различные традиционные игры, такие как «Ладушки», а также игры, основанные на подражании предметно-игровым действиям взрослого.

Задание 1. «Кто спрятался под платочком?»

Цель: учить ребёнка фиксировать внимание на себе и на другом человеке.

Оборудование: тонкий платок.

Ход задания: взрослый накрывает голову ребёнка платком, спрашивает: «А где же (имя ребёнка)?» - «Нет (имя ребёнка)!» - снимает платок и оживлённо произносит «Да вот же (имя ребёнка)!», можно провести рукой ребёнка по го- 


\section{Педагогический ИМИДЖ}

Гау ДПО ИРО

лове, ладонью ребёнка показать на него и сказать: «Я!». Затем накидывает платок на себя, спрашивает: «Где тётя?» Ребёнок должен стянуть платок, взрослый говорит: «Вот тётя!»

Задание 2. «Кто как кричит?» (со стихами)

Цель: продолжение формирования эмоционального контакта со взрослым, обучение ребёнка звукоподражанию животных с определёнными звукосочетаниями.

Оборудование: игрушки домашние животные (гусь, корова, овечка, кошка).

Ход игры: взрослый усаживает ребёнка рядом с собой и достаёт игрушки, называя каждую из них, начинает читать стихотворение:

Говорит корова: «Мy-y-y!

Молока налить кому?»

Достаёт следующую игрушку:

$$
\text { Говорит овечка: «Ме-е-е! }
$$

Дайте вкусной травки мне!»

Взрослый спрашивает: «Как говорит корова?» - показывает на игрушку, если ответа ребёнка не последует, отвечает сам: «Му-у-у!»

Достаёт следующую игрушку:

$$
\begin{gathered}
\text { «Га-га-га! - гогочет гусь. - } \\
\text { Никого я не боюсь!» }
\end{gathered}
$$

Взрослый обращает внимание ребёнка: «Как гусь гогочет?» - «Га-га-га!»

А как овечка говорит? - «Ме-е-е!»

Снова достаёт игрушку:

$$
\begin{gathered}
\text { «Мяу-мяу! - плачет киска. - } \\
\text { У меня пустая миска!» }
\end{gathered}
$$

Взрослый снова акцентирует внимание на всех животных, называет их и спрашивает у малыша, кто как подаёт голос.

Задание 3. "Послушные ручки (песенка)»

Цель: восстанавливать действия, подражая действиям взрослого, вызывать интерес к музыкальным играм.

Оборудование: не требуется.

Ход игры: взрослый садится на пол напротив ребёнка, напевает песенку, показывает движения по тексту и побуждает ребёнка к подражанию:

$$
\begin{aligned}
& \text { Ручками мы хлопнем - да-да-да! } \\
& \text { Ручками мы хлопнем - да-да-да! }
\end{aligned}
$$

Взрослый хлопает в ладоши, протяжно пропевает слоги «да-да-да», стремится, чтобы ребёнок наблюдал за его артикуляцией и подпевал. Далее взрослый машет руками и пропевает «да».

$$
\begin{aligned}
& \text { Ручками помашем - да-да-да-да! } \\
& \text { Ручками попляшем - да-да-да-да! }
\end{aligned}
$$

В конце игры взрослый эмоционально хвалит ребёнка: «Молодец, (имя ребёнка)! Ты хорошо хлопал вместе с тётей «да-да-да»!»

Задание 4. «Покатаемся на машине!»

Цель: закреплять положительные эмоции от контакта со взрослым, вызывать звукоподражание.

Оборудование: коврик или покрывало.

Ход игры: взрослый укладывает ребёнка на коврике или на покрывале. Ими- 
тирует звуки машины, тянет уголок коврика к себе, как импровизированную машину, чтобы он скользил по полу. При этом можно напевать песенку:

Машинка-машинка, ты нас покатай-ка,

Машинка-машинка, скорей поезжай-ка!

Движение останавливает и выразительно пропевает, наклоняясь к ребёнку: «Би-би-би! Би-би-би!»

Продолжает движение, напевая:

Машинка-машинка, ты всех обгони-ка!

Машинка-машинка, направо сверни-ка!

Снова останавливается и пропевает выразительно:

«Би-би-би! Би-би-би!»

Продолжает движение, напевает:

Машинка-машинка, вези нас домой!

Машинка-машинка, приехали! Стой!

Комментарии: при проведении этой игры следует делать паузу, побуждая эмоционально, подбадривая голосом, используя подражательные звуки машины.

Третий этап - активизация и побуждение к поддержанию эмоционального контакта со взрослым.

Задание 1. "Cыпь песок!»

Цель: активизировать самостоятельные действия, при затруднениях, использовать показ действий.

Оборудование: таз с песком, водяная игрушечная мельница, лопатки/чашки/ маленькие игрушечные ведёрки.

Ход игры: взрослый сыплет песок в мельницу с помощью выбранного им инструмента. Если ребёнок заинтересовывается происходящим и подходит ко взрослому, взрослый спрашивает: «Будешь играть? Садись!» - и даёт ребёнку выбрать, чем малыш будет насыпать песок. После того, как ребёнок выберет инструмент, взрослый произносит: «Сначала я!» - и высыпает песок в мельницу «А теперь ты! Делай, как я!», - если ребёнку требуется помощь, задание выполняется рука в руке. Взрослый привлекает внимание ребёнка к крутящемуся колесу мельницы, радуется, передавая своё настроение ребёнку. Так продолжается игра, при этом очень важно, чтобы ребёнок соблюдал очерёдность. Если ребёнок не хочет взаимодействовать по очереди, взрослый говорит: «Жди, (имя ребёнка). Сначала я, потом ты!»-спокойно и сосредоточенно.

Задание 2. «Найди игрушку» (в тазике с фасолью)

Цель: вызвать эмпатию у ребёнка, формировать положительный спокойный отклик на взаимодействие со взрослым, восстановить поисковые действия рук, подражательные умения.

Оборудование: таз с фасолью (другой крупной крупой), игрушки (фигурки животных).

Ход игры: взрослый изображает, как игрушки «купаются» в тазике и вдруг пропадают внутри. С изумлением взрослый произносит: «Нету! Куда делись игрушки? Помоги мне их найти!» - ждёт реакции ребёнка. Если реакции не последовало, совершает поисковые движения руками в тазике и снова повторяет: «Нету...» Если ребёнок начинает помогать взрослому в процессе поиска игрушек, взрослый благодарит и подбадривает ребёнка, эмоционально подкрепляя 
всё, что тот делает: «Здорово! Ты такой хороший помощник!» Если ребёнок позволяет тактильный контакт, в конце игры можно погладить ребёнка по спине или приобнять, ещё раз поблагодарив за помощь.

Комментарии: количество игрушек в тазу регулируется педагогом или взрослым в зависимости от уровня истощаемости ребёнка; при необходимости данная игра может проводиться не один раз с разными предметами, в том числе с бытовыми принадлежностями (расчёской, зубной щёткой и т. д.).

Задание 3. "Далеко-далеко»

Цель: умение сотрудничать со взрослым, допевать песенку по образцу, находить игрушку среди других.

Оборудование: игрушки - корова, коза, конь, кошка.

Ход задания: взрослый предлагает ребёнку слушать песенку и брать ту игрушку, про которую поётся в песенке. «Далеко-далеко на лугу пасутся коо-о...» (Взрослый достаёт игрушку кошку.) Спрашивает: «Кошки?» Отвечает сам: «Нет-нет-нет, не кошки!» «Далеко-далеко на лугу пасутся ко-о...» (Достаёт игрушку коня.) Спрашивает: «Кони?» Ждёт реакции ребёнка, может подсказать отрицательным жестом. Если реакции нет, продолжает петь сам: «Нетнет-нет, не кони!»

Та же игра продолжается со всеми животными до строчки: «Далеко-далеко на лугу пасутся ко-о...» (достаёт игрушку корову). Спрашивает: «Коровы?»кивает головой ребёнку или подсказывает, ребёнок должен подхватить и сказать: «Да!», тогда взрослый продолжает петь: «Да-да-да! Правильно, коровы! Пейте дети молоко - будете здоровы!»

Комментарии: данное задание проводится многократно. Когда ребёнок запоминает текст песни, взрослый просит помогать ему и останавливается на словах «на лугу пасутся» и там, где требуется ответ ребёнка, чтобы ребёнок мог продолжить песенку. Можно показывать игрушку ребёнку и просить называть самостоятельно, а затем просить спеть песенку одному, тогда уже взрослый будет в роли отвечающего на вопросы поющего.

\section{СЕРИЯ (2) предметно-игровых заданий, направленных на то, чтобы вызывать у ребёнка интерес к новому взрослому и воспроизводить до- ступным способом предметно-игровые действия}

Вторая серия игровых заданий направлена на восстановление у ребёнка активных предметно-игровых действий и манипуляций с игрушкой.

Задание 1. «Построим забор»

Цель: восстановление интереса к строительным играм, обучение выполнению предметно-игровых действий-подражаний.

Оборудование: машина, кирпичики, домик, игрушка (петушок).

Ход игры: взрослый обращает внимание ребёнка на домик, в котором живёт петушок. Предлагается построить забор из кирпичиков вокруг домика петушка для защиты от лисы. Взрослый просит ребёнка загрузить машинку кирпичиками и отвезти их к домику петушка. Затем взрослый и ребёнок начинают строить забор. Взрослый показывает, как строить: «Делай как я!», а ребёнок выполняет действия-подражания.

Задание 2 «Кати машинку!» 
Цель: восстановление непосредственного контакта между ребёнком и взрослым, предметно-игрового действия с игрушкой.

Оборудование: импровизированная горка (доска), машинки (грузовики или такие, куда поместится маленькая игрушка), игрушки по количеству машинок.

Ход игры: у взрослого машинки-грузовики, в них сидят животные или другие игрушки, помещающиеся в кузов. Взрослый ставит машинку на длинную доску и просит ребёнка: «Заводи машинку!», затем сам говорит: «Вжжж»- и спускает машинку с «горки». Ставит следующую машинку на «горку», но не отпускает, а ждёт реакции ребёнка, помогает командой: «Заводи машинку!»

Комментарии: Если ребёнок не даёт ответа, желательно повторить спуск машинок ещё 2-3 раза, привлекая внимание к игрушкам, сидящим в грузовичках: «Посмотри, лисичка\зайчик\котик хочет покататься! Помоги!»

Задание 3. «Лови мяч!»

Цель: установление эмоционального контакта между ребёнком и взрослым, восстановление согласованности действий обеих рук.

Оборудование: мяч среднего размера.

Ход задания: взрослый сидит напротив ребёнка на ковре, достаёт мяч, ловит взгляд ребёнка и командует: «Лови мяч!» Ребёнок самостоятельно (или с помощью другого взрослого) ловит мяч двумя руками. Взрослый снова говорит: «Кати мяч!» Ребёнок должен самостоятельно (или с помощью) последовать инструкции. Игра продолжается до тех пор, пока ребёнок не потеряет интерес. Важно отслеживать глазной контакт с ребёнком во время проведения игры, улыбаться ему и хвалить за успех.

Задание 4. «Поймай рыбку!»

Цель: восстановление предметно-орудийных действий с сачком.

Оборудование: таз с водой, пластмассовые рыбки, сачки.

Ход задания: взрослый бросает пластмассовых рыбок в таз с водой и говорит: «Посмотри, это рыбки! Помоги поймать» Показывает, как ловить сачком. Затем даёт попробовать ребёнку. Если ребёнок успешен, взрослый хвалит его, а затем говорит: «Теперь я!» И снова ловит рыбку, следя за тем, что ребёнок дожидается своей очереди. «Теперь (имя ребёнка)!» - говорит взрослый, давая понять, что теперь снова настала очередь малыша.

Задание 5. "Чудесный мешочек»

Цель: восстановление предметно-игровых действий, тактильного восприятия.

Оборудование: мешок, кукла, мячик, молоточек и колокольчик.

Ход задания: взрослый показывает ребёнку мешочек и говорит: «Посмотри, это чудесный мешочек! Что там? Пощупай». Предлагает ребёнку опустить руку в мешок и достать игрушку. После того, как ребёнок достанет первый предмет, взрослый спрашивает: «Что это? Что можно делать?» Молоточком стучать. Кукоу - качать. Мячик - катить. Колокольчик - звенеть.

Данные серии заданий должны помочь ребёнку научиться взаимодействовать со взрослым, принимать правила игры и получать положительные эмоции от игры со взрослым. 


\section{Обсуждение динамики восстановления ребёнка Д. за период стацио- нарной реабилитации}

Диагностическое обучение включало в себя разработку и проведение серий заданий на материале обследования.

При проведении диагностического обучения: Д. начал обращать внимание на педагога и стал брать предметы: сперва левой рукой, а потом и более пострадавшей - правой. Поначалу мальчик не хотел контактировать с посторонними людьми, но вскоре контакт с ним удалось наладить, и мы наблюдали в процессе предметно-игровых действий его улыбку. Он начал реагировать на голос близкого взрослого (улыбался, поворачивал голову), на речь педагога, стал выполнять простую речевую инструкцию. Его зрительная ориентировка восстанавливалась медленнее, но после нескольких занятий Д. начал следить глазами за людьми и предметами: сперва движения глаз были ступенчатыми, но со временем стали всё более устойчивыми.

Достаточно долго Д. совсем молчал, но ещё через несколько занятий у него появились произвольные вокализации, а затем начала потихоньку восстанавливаться активная речь. В процессе занятий мы наблюдали динамику: от отдельных невербальных реакций (направленный в сторону предмета взгляд, поворот головы в сторону взрослого, изменение мимики лица), а затем и вербальных - голосовых проявлений (от шёпотных звуков до громких слов).

К моменту выписки из стационара Д. был способен уже на достаточно сложные произвольные движения руками: мог пользоваться жестами, в том числе, указательным, бросать предметы, манипулировать с предметами в зависимости от их свойств (хотя последствия травмы сказывались на точности движений). Помимо этого мальчик мог действовать в соответствии с речевой инструкцией и с игровой ситуацией, немного разговаривал: адекватно использовал простую фразу, мог закончить строку в знакомом до травмы стихотворении.

Наблюдение показало, что мальчик стал положительно откликаться на своё имя, смотреть в глаза взрослому, проявлять интерес к предметно-игровым действиям, повторять за взрослым простые движения рук и действия с предметом. Кроме этого, он научился держать ложку и кусок хлеба, подносить его к рту.

По таблице оценки психической активности его возможности составили 23 балла (из 36).

\section{Заключение}

Представленная серия игровых заданий для восстановительной работы с ребёнком после нейротравмы имеет особенности:

- поэтапное предъявление игр в ходе коррекционного обучения;

- на начальном этапе акцентируется внимание на восстановлении эмоционального контакта между ребёнком и взрослым, активном привлечении внимания ребёнка ко взрослому;

- затем на вовлечении ребёнка в эмоционально положительное взаимодействие со взрослым путём совместных предметно-игровых действий;

- завершается серия диагностического обучения играми, направленными на побуждение ребёнка к самостоятельным (доступным) движениям и действиям), закреплению ориентировки на взрослого.

В ходе экспериментальной работы было важно включить близкого взросло- 
го в игровую ситуацию, предлагаемую ребёнку. После каждого занятия специалист проводил короткую беседу разъяснительного и информирующего характера, а также отдельно показывал некоторые приёмы обучения.

Таким образом, педагогические средства реабилитации в условиях стационара показали свою эффективность с пациентом Д. (2 г. 9. мес.). Использование в диагностическом обучении специально разработанной серии игр позволило наблюдать положительную динамику восстановления социальных умений в коммуникации и взаимодействии с близкими и новым взрослым.

\section{Заявленный вклад авторов}

Камелькова А. И.: анализ теоретической части статьи, подбор литературных источников, подготовка статьи к публикации.

Колдышева П. П.: подготовка аннотации, введения и теоретической части описания.

Мартышевская Д. М.: анализ и обработка экспериментальных данных, вывооов исследования.

Тарновская П. А.: участие в написании аннотации, подготовка выводов, описание практической части исследования.

Все авторы прочитали и одобрили окончательный вариант рукописи.

\section{Список литературы}

1. Аксарина Н. М. Воспитание детей раннего возраста ; 2-е изд., испр. и доп. М. : Медицина, 1972. 264 с.

2. Браткова М. В., Закрепина А. В. Экспериментальное исследование типологических особенностей психической активности детей после травмы // Психология обучения. 2017. № 9. С. 15-27.

3. Браткова М. В. Формирование предметных действий у детей раннего возраста с органическим поражением центральной нервной системы [Электронный ресурс] // Альманах Института коррекционной педагогики. 2008. № 12. URL: https://alldef.ru/ru/ articles/almanah-12/ (дата обращения: 12.08.2018).

4. Валиуллина С. А. Черепно-мозговая травма у детей: социально-эпидемиологические особенности и качество жизни [Электронный ресурс] // Альманах Института коррекционной педагогики 2016. № 25 (дата обращения: 23.06.2019).

5. Валиуллина С. А., Сиднева Ю. Г., Закрепина А. В., Фуфаева Е. В., Тютюкина А. И., Быкова В. И., Боттаева Ж. С., Аркатова Е. А., Борисова Н. В., Браткова М. В. Система ранней комплексной психиатрической, психолого-педагогической реабилитации детей с тяжелой черепно-мозговой травмой. Ч. 1 / сниженный уровень сознания вегетативный статус, минимальное сознание / под ред. С. А. Валиуллиной. М. : ПАРАДИГМА, 2018. 48 с.

6. Волков Е. В. Роль сосудистых и иммунологических нарушений в формировании травматической болезни головного мозга с сочетанной челюстно-лицевой травмой у детей : дис. ... канд. мед. наук : 14.01.11. М., 2015. 146 с.

7. Галигузова Л. Н., Мещерякова С. Ю. Педагогика детей раннего возраста: учеб. пособие для студентов вузов. М. : ВЛАДОС, 2010. 301 с. 
ГАУ ДПО ИРО

8. Галигузова Л. Н. Творческие проявления в игре детей раннего возраста // Вопросы психологии. 1993. № 2. С. 17-25.

9. Дидактические игры и занятия с детьми раннего возраста / под ред. С. Л. Новоселовой ; 3-е изд., испр. М. : Просвещение, 1977. 176 с.

10. Закрепина А. В. Коррекционное обучение детей с тяжелой черепно-мозговой травмой (в условиях стационарной реабилитации) : дис. ... д-ра пед. наук : 13.00.03. М. : 2014. 184 c.

11. Закрепина, А. В., Браткова М. В., Мамонтова Н. А. Способ оценки психической активности детей с тяжелой черепно-мозговой травмой / Правообладатель: ГБУЗ г. Москвы. Научно-исследовательский институт неотложной детской хирургии и травматологии Департамента здравоохранения города Москвы. Свидетельство о государственной регистрации базы данных № 2681712. Дата регистрации в Реестре баз данных : 12.03.2019. Номер заявки : 201713849.

12. Игры и занятия с детьми раннего возраста с психофизическими нарушениями : метод. пособие для родителей и пед. дошк. учреждений / под ред. Е. А. Стребелевой, Г. А. Мишиной ; 2-е изд. М. : Экзамен, 2006158 с.

13. Каримов Р. Х., Исмагилов Д. О. Распространенность нейротравм и их последствий в Республике Татарстан // Вестник современной клинической медицины 2013. № 5. C. 108-114.

14. Лазуренко С. Б. Психическое развитие детей с нарушениями здоровья в раннем возрасте. М. : Логомаг, 2015. 284 с.

15. Мастюкова Е. М. Ребенок с отклонениями в развитии: Ранняя диагностика и коррекция. М. : Просвещение, 1992. 95 с.

16. Мухина В. С. Детская психология. М. : Просвещение, 2012. 272 с.

17. Нейротравматология. Справочник. / под ред. А. Н. Коновалова, Л. Б. Лихтермана, А. А. Потапова. Ростов н/Д : Феникс. 1999. 576 с.

18. Петухова Н. М., Кучук И. В. Нейротравмы у новорожденных // Вестник Алматинского государственного института усовершенствования врачей. 2010. № 1. С. 53-54.

19. Сороковиков В. А., Бывальцев В. А., Калинин А. А., Панасенков С. Ю., Егоров А. В. Современные подходы к лечению пациентов с позвоночно-спинальной травмой [Электронный ресурс] // Бюллетень ВСНЦ СО РАМН 2011. № 1 (77). Ч. 2. С. 272-274. URL : https://cyberleninka.ru/article/n/sovremennye-podhody-k-lecheniyu-patsientov-spozvonochno-spinalnoy-travmoy/viewerhttps://alldef.ru/ru/articles/almanah-12/ (дата обращения: 12.08.2018).

20. Урунтаева Г. А. Психология дошкольного возраста: учебник для студ. учреждений высш. проф. образования. М. : Академия, 2014. 272 с.

21. Фуфаева Е. В., Быкова В. И., Закрепина А. В., Боттаева Ж. С., Валиуллина С. А., Семенова Ж. Б. Психолого-педагогическая реабилитация на ранних этапах восстановления детей после тяжелой черепно-мозговой травмы (организационные аспекты) // Вестник неврологии, психиатрии и нейрохирургии. 2014. № 4. С. 65-77.

22. Щедренок В. В., Гуманенко Е. К., Кирьянова В. В., Жарова Е. Н., Симонова И. А., Потемкина Е. Г., Зуев И. В., Могучая О. В. Принципы ранней хирургической реабилитации нейротравмы // Вестник хирургии имени И. И. Грекова. 2013. Т. 172. № 5. C. 51-55.

23. Эльконин Д. Б. Заметки о развитии предметных действий в раннем детстве // Детская психология / ред.-сост. Б. Д. Эльконин. М. : Академия, 2007. 384 с.

24. Standards for Surveillance of Neurotrauma / Editors: D. J. Thurman, J. F. Kraus, C. J. Romer. Geneva: WHO Safety Promotion and Injury Control Division of Emergency and Humanitarian Action. 1995. 41 p.

25. Zakrepina A., Strebeleva E. Mental Activity in Preschool Children with Severe Craniocerebral Trauma // Acta Neuropsychologica. 2018; 16(1):69-81. (In Eng.). DOI: https://doi.org/10.5604/01.3001.0011.7066. 


\title{
Pedagogical Tools in Rehabilitation of Toddlers with Neurotrauma: Educational Game Series to Recover Productive Interaction with Adults
}

\author{
Alena I. Kamelkova, Polina P. Koldysheva, \\ Daria M. Martyshevskaya, Polina A. Tarnovskaya \\ Moscow Pedagogical State University, Moscow
}

\begin{abstract}
Introduction. The study addresses the relevant issues of rehabilitation of children with neurotrauma (in a hospital) using pedagogical tools. The study aims to develop a special program to restore interaction between a child and an adult after neurotrauma. The dynamics of social skills recovery during rehabilitation process for a child with neurotrauma is presented. The paper includes a rehabilitation program, which has an educational game series to recover the productive interaction.

Materials and methods: The following clinical case is described: a 2.7-year-old boy D., (with closed TBI, severe brain contusion). The methods employed are pedagogical examination, diagnostic education, observation.

Results: The proposed educational game series had positive dynamics of recovery in child $D$.

Conclusion. This issue can be developed through the new special educational methods for children in the early stage of rehabilitation after neurotrauma. The results can be used by special-need teachers for children after severe TBI.
\end{abstract}

Keywords: early age, neurotrauma, social contact, interaction, traumatic brain injury, rehabilitation, special education, child with neurotrauma, child with head injury

\section{Камелькова \\ Алена Игоревна}

магистрант

https://orcid.org/

0000-0003-0767-7826

Московский педагогический государственный университет

119991, Россия, г. Москва, ул. Малая Пироговская, 1, стр. 1

тел.: +7(499)2450310

e-mail:kamelkovaa@rambler.ru

\section{Kamelkova Alena Igorevna}

Master Student

https://orcid.org/ 0000-0003-0767-7826

Moscow Pedagogical State University

1/1 M. Pirogovskaya St, Moscow, Russia, 119991

tel.:+7(499)2450310

e-mail:kamelkovaa@rambler.ru 


\section{Колдышева \\ Полина Павловна}

Магистрант

https://orcid.org/

0000-0001-8983-907X

Московский педагогический государственный университет

119991, Россия, г. Москва, ул. Малая Пироговская, 1, стр. 1

тел.: +7(499)2450310

e-mail: pollykoldysheva@gmail.com

\section{Koldysheva \\ Polina Pavlovna}

Master Student
https://orcid.org/
0000-0001-8983-907X

Moscow Pedagogical State University

1/1 M. Pirogovskaya St, Moscow, Russia, 119991

tel.: +7(499)2450310

e-mail:pollykoldysheva@gmail.com

\section{Мартышевская \\ Дарья Михайловна}

магистрант

https://orcid.org/

0000-0002-1236-005X

Московский педагогический государственный университет

119991, Россия, г. Москва, ул. Малая Пироговская, 1, стр. 1

тел.: +7(499)2450310

e-mail:DT7744@yandex.ru

\section{Martyshevskaya \\ Daria Mihaylovna}

Master Student

https://orcid.org/

0000-0002-1236-005X

Moscow Pedagogical State University

1/1 M Pirogovskaya St, Moscow, Russia, 119991

tel.: +7(499)2450310

e-mail:DT7744@yandex.ru

Tarnovskaya

Polina Alekseevna

Master Student

https://orcid.org/

0000-0002-4633-6015

Moscow Pedagogical State University
1/1 M Pirogovskaya St, Moscow, Russia, 119991

tel.: +7(499)2450310

e-mail:polalala96@gmail.com тел.: +7(499)2450310

e-mail:polalala96@gmail.com
119991, Россия, г. Москва, ул. Малая Пироговская, 1, стр. 1 